\title{
1. Introduction to International Commercial Arbitration in the European Union
}

\subsection{INTRODUCTION}

Brexit - the formal process of the United Kingdom ('UK') exiting the European Union ('EU') - has not only dominated the public and political domain in recent times, but it has, to a great extent, become a majorly debated academic topic in the EU and, in particular, generated a lot of uncertainty, with emerging challenges to the international legal order within the UK and the EU. The main point of discussion is the potential impact of Brexit on the already established and functioning systems of the UK as well as the future relationship between the UK and the EU.

As an economic and political union, the EU facilitates the free movement of persons, goods, capital and services across the Member States of the EU. This economic integration in the EU allows for closer cross-border relationships and cooperation between the Member States' citizens and businesses. Indeed, cross-border relationships may not only be formed between EU citizens and businesses but also between EU citizens and non-EU parties, thereby increasing the possibility of cross-border disputes, which would often require the use of private international law mechanisms to resolve them. Private international law concerns the relationships that transcend national boundaries and provides mechanisms that may be employed to deal with the problems that may arise through such cross-border relationships. For example, disputes arising in the context of cross-border relationships and transactions may be complicated, particularly with regard to determining the question of jurisdiction, the question of choice of law and the question of the recognition and enforcement of decisions.

International commercial arbitration as a mechanism of private international law provides an effective means of resolving cross-border disputes between commercial parties. It aims to promote international trade through efficient dispute resolution by allowing commercial actors the freedom to regulate the 
conduct of the arbitration process, thus acknowledging the importance of the doctrine of party autonomy. As Lord Mustill rightly stated:

Party autonomy emphasises that arbitration is a consensual process, and that national courts should, within very broad limits, recognise and give effect to any agreement between the parties, express or tacit, as to the way in which the arbitration should be conducted. It is now widely recognised as a first principle of arbitration law, and the English courts in common with those of other nations with developed systems of arbitration law strive to give effect to it. ${ }^{1}$

Arbitration is distinguished from other types of Alternative Dispute Resolution 'ADR' methods, for example conciliation, mediation and negotiation, because unlike these types of ADR, arbitral awards rendered by arbitral tribunals are binding on the parties just like the judgments of the national courts. Nevertheless, arbitration is generally perceived to have certain advantages over court litigation, such as confidentiality and privacy, procedural flexibility, informality of proceedings and the widespread recognition and enforcement of arbitral awards under the New York Convention. ${ }^{2}$ The New York Convention, to which all the Member States of the EU are signatories, requires that the parties' arbitration agreements are enforced by the national courts and that arbitral awards made by arbitrators are recognised and enforced subject to the limited grounds for non-recognition and enforcement of the arbitral awards contained in Art V of the New York Convention. ${ }^{3}$

However, the treatment of international commercial arbitration within the EU has been intensely debated, ${ }^{4}$ particularly in relation to the scope of

Coppee-Lavalin v Ken Ren [1994] 2 Lloyd's Rep 109, 114.

Convention on the Recognition and Enforcement of Foreign Arbitral Awards, signed at New York 1958 (hereinafter 'New York Convention'); European Commission Staff Working Paper (Impact Assessment) Accompanying document to the Proposal for a Regulation of the European Parliament and of the Council on jurisdiction and the recognition and enforcement of judgments in civil and commercial matters (Recast) SEC [2010] 1547 final 35 (hereinafter 'Impact Assessment') 34.

3 A list of all the Contracting States of the New York Convention is available at [http://www.newyorkconvention.org/contracting-states/list-of-contracting-states] accessed 18 January 2016.

4 See the discussions in: Bernard Audit, 'Arbitration and the Brussels Convention' (1993) ArbIntl 1; Peter Kaye, 'The Judgments Convention and Arbitration: Mutual Spheres of Influence' (1991) ArbIntl 289; Peter Kaye, 'The EEC and Arbitration: The Unsettled Wake of The Atlantic Emperor' (1993) ArbIntl 27; Paul Jenard, 'Opinion' (1991) ArbIntl 243; Peter Schlosser, 'The 1968 Brussels Convention and Arbitration' (1991) ArbIntl 227; Dominique T Hascher, 'Recognition and Enforcement of Judgments on the Existence and Validity of an Arbitration Clause under the Brussels Convention' (1997) ArbIntl 33; Jean-Paul Beraudo, 'The Arbitration Exception of the Brussels and Lugano Conventions: Jurisdiction, Recognition and Enforcement of Judgments' (2001) 
the arbitration exclusion contained in the 'Brussels I Regime', the three EU Brussels instruments on jurisdiction and the recognition and enforcement of judgments in civil and commercial matters. ${ }^{5}$ The original Brussels Convention ${ }^{6}$

JIntlArb 13; Jacomijn J van Haersolte-van Hof, 'The Arbitration Exception in the Brussels Convention: Further Comment' (2001) JIntlArb 27; Hans van Houtte, 'May Court Judgments that Disregard Arbitration Clauses and Awards Be Enforced under the Brussels and Lugano Conventions?' (1997) ArbIntl 85; Clare Ambrose, 'Arbitration and the Free Movement of Judgments' (2003) ArbIntl 3; 'The Brussels Convention: The Arbitration Exception' (1991) ArbIntl 179; Hakeem Seriki, 'Litigating in Breach of Arbitration: What Exactly Does Article 1(4) of the Brussels Convention Cover?' (2000) Arbitration 49. See also the decisions by the Court of Justice of the European Union (CJEU): Case C-190/89 Marc Rich \& Co v Societa Italiana Impianti SpA [1991] ECLI: EU:C:1991:319; Case C-391/95 Van Uden Maritime BV v Kommanditgesellschaft in Firma Deco-Line [1998] ECLI:EU:C:1998:543; Case C-185/07 West Tankers Inc $v$ Allianze SpA [2009] ECLI:EU:C:2009:69.

5 'Brussels I Regime' means the three EU Brussels instruments on jurisdiction and the recognition and enforcement of judgments in civil and commercial matters, namely (1) Brussels Convention on jurisdiction and the enforcement of judgments in civil and commercial matters [1972] OJ L299/1 (hereinafter 'Brussels Convention'); (2) Council Regulation (EC) No 44/2001 on jurisdiction and the recognition and enforcement of judgments in civil and commercial matters [2000] OJ L12/1 (hereinafter 'Brussels I Regulation'); and (3) Regulation (EU) No 1215/2012 of the European Parliament and of the Council of 12 December 2012 on jurisdiction and the recognition and enforcement of judgments in civil and commercial matters (recast) [2012] OJ L351/1 (hereinafter 'Brussels I Recast').

6 The Brussels Convention was amended by several Accession Conventions as new Member States joined the European Union: (1) Council Convention on the accession of the Kingdom of Denmark, of Ireland and of the United Kingdom of Great Britain and Northern Ireland to the Convention on jurisdiction and the enforcement of judgments in civil and commercial matters and to the Protocol on its interpretation by the Court of Justice [1978] OJ L304/1; (2) Convention on the accession of the Hellenic Republic to the Convention on jurisdiction and enforcement of judgments in civil and commercial matters and to the Protocol on its interpretation by the Court of Justice with the adjustments made to them by the Convention on the accession of the Kingdom of Denmark, of Ireland and of the United Kingdom of Great Britain and Northern Ireland [1982] OJ L388/1; (3) Convention on the accession of the Kingdom of Spain and the Portuguese Republic to the Convention on jurisdiction and the enforcement of judgments in civil and commercial matters and to the Protocol on its interpretation by the Court of Justice with the adjustments made to them by the Convention on the accession of the Kingdom of Denmark, of Ireland and of the United Kingdom of Great Britain and Northern Ireland and the adjustments made to them by the Convention on the accession of the Hellenic Republic [1989] OJ L285/1; (4) Convention on the accession of the Republic of Austria, the Republic of Finland and the Kingdom of Sweden to the Convention on jurisdiction and the enforcement of judgments in civil and commercial matters and to the Protocol on its interpretation by the Court of Justice, with the adjustments made to them by the Convention on the accession of the Kingdom of Denmark, of Ireland and of the United Kingdom of Great Britain and Northern Ireland, by the 
was replaced by the Brussels I Regulation, which was in turn replaced by the Brussels I Recast, the current EU legislative framework regulating the jurisdiction and the recognition and enforcement of judgments in civil and commercial matters. Arbitration was excluded from the scope of the original Brussels Convention by virtue of Art 1(4), and the same arbitration exclusion is retained in Art 1(2)(d) of the Brussels I Regulation and the Brussels I Recast. Yet, the interaction of commercial arbitration with the EU Brussels I Regime remains controversial despite the arbitration exclusion in the Brussels I Regime. The controversy is largely based on the unregulated interface between commercial arbitration and the Brussels I Regime, which is created by the fact that neither the Brussels I Regime nor the New York Convention provide mechanisms to properly address the situation in which civil and commercial matters that are ordinarily addressed in international commercial arbitration may also fall within the material scope of the Brussels I Regime. It follows that international commercial arbitration based on the New York Convention and the EU international commercial litigation based on the Brussels I Regime may interact in the process of the arbitral tribunals and courts of the Member States exercising jurisdiction in civil and commercial matters. As both instruments in any such interaction require respect and obedience, but do not otherwise regulate their potential conflict, this may lead to an undesirable degree of uncertainty between the two regimes. ${ }^{7}$

The Court of Justice of the European Union 'CJEU' (formerly European Court of Justice 'ECJ') plays an important role by interpreting the relevant provisions of the Brussels I Regime upon receiving references for preliminary rulings from the courts of the EU Member States. ${ }^{8}$ For example, in answering

Convention on the accession of the Hellenic Republic and by the Convention on the accession of the Kingdom of Spain and the Portuguese Republic [1996] OJ C15/1.

7 A study on the Legal Instruments and Practice of Arbitration in the EU: Study for the JURI Committee [2014] requested by the Committee on Legal Affairs (PE 509.988 EN) 186.

8 The preliminary reference procedure in Art 267 of the Treaty on the Functioning of the European Union (TFEU) gives the CJEU the opportunity to deliver preliminary rulings on the validity and interpretation of EU law to ensure its uniform application within the European Union judicial area. See generally, Consolidated versions of the Treaty on European Union and the Treaty on the Functioning of the European Union, signed at Lisbon, 13 December 2007 [2012] OJ C326, Art 267; Protocol on the interpretation by the Court of Justice of the Convention of 27 September 1968 on jurisdiction and the enforcement of judgments in civil and commercial matters; Morten Broberg and Niels Fanger, Preliminary References to the European Court of Justice (OUP 2010); Rudolf Geiger, Daniel-Erasmus Khan and Markus Kotzur, European Union Treaties (CH Beck. Hart 2015) 893; Klaus-Dieter Borchardt, The ABC of European Union Law (Publications Office of the European Union 2010) 66. However, it should be borne in mind that arbitrators do not constitute a court or tribunal of the Member States for 
the preliminary question on the compatibility of anti-suit injunctions with the Brussels I Regime, the CJEU prohibited the use of anti-suit injunctions, a mechanism generally adopted by the courts of common law countries to give effect to choice of court/arbitration agreements, on the basis that it is incompatible with the scheme of the Brussels I Regime. ${ }^{9}$ The Brussels I Recast updated the provisions of the Brussels I Regulation whilst adhering to its basic structure and objectives on jurisdiction and the recognition and enforcement of judgments in civil and commercial matters. ${ }^{10}$ Recital 34 of the Brussels I Recast ensures the continuity of the Brussels Convention, the Brussels I Regulation and the Brussels I Recast, as well as the interpretation by the CJEU of the various versions of the Brussels I Regime. ${ }^{11}$ Therefore, the cases decided under the Brussels Convention and the Brussels I Regulation continue to apply to the Brussels I Recast provided that they are decided on the same substantive provision(s). ${ }^{12}$ It follows that the CJEU, when faced with a matter falling within the material scope of the Brussels I Recast, will generally refer to its previous case law on the Brussels I Regulation and the Brussels Convention provided

the purposes of a preliminary reference to the CJEU. Case 102/81 Nordsee Deutsche Hochseefischerei GmbH v Reederei Mond Hochseefischerei Nordstern AG [1982] ECLI:EU:C:1982:107 [10]; George Bermann, 'Navigating EU Law and the Law of International Arbitration' (2012) ArbIntl 397, 404.

9 Case C-159/02 Turner v Grovit [2005] ECR 1-03565; Case C-185/07 West Tankers (n 4).

10 Opinion of Advocate General Kokott in Case C-185/07 West Tankers (n 4) para 29.

11 Brussels I Recast (n 5) recital 34 provides that continuity between the 1968 Brussels Convention, Regulation (EC) No 44/2001 and the Brussels I Recast should be ensured, and transitional provisions should be laid down to that end. The same need for continuity applies as regards the interpretation by the Court of Justice of the European Union of the 1968 Brussels Convention and of the Regulations replacing it.

12 Elizabeth Crawford and Janeen Carruthers, 'Connection and Coherence between and among European Instruments in the Private International Law of Obligations' (2014) ICLQ 1, 3; Adrian Briggs, Private International Law in English Courts (OUP 2014) para 4.33; Trevor Hartley, 'The Brussels I Regulation and Arbitration' (2014) ICLQ 843, 861; Paolo Galizzi, Jurisdiction and Enforcement of Judgments in Civil and Commercial Matters: ECJ Judgments, vol 1 (British Institute of International and Comparative Law 2002). 
that the provisions are similar. ${ }^{13}$ This is done to ensure continuity, certainty and the uniform interpretation of similar provisions of the Brussels I Regime. ${ }^{14}$

Notwithstanding the foregoing, the CJEU case law on the scope of the arbitration exclusion in the Brussels Convention and the Brussels I Regulation may not be entirely applicable to the Brussels I Recast as the new recital 12 of the Brussels I Recast contains novel provisions on the scope of the arbitration exclusion. Recital 12 contains four paragraphs which provide guidance on the interpretation of the arbitration exclusion in the operative part of the Brussels I Recast. ${ }^{15}$ The first paragraph allows the courts of the Member States the liberty to rule on the existence and validity of arbitration agreements. The second paragraph excludes the decision of the courts of the Member States on the existence and validity of arbitration agreements from the rules of recognition and enforcement laid down in the Brussels I Recast. The third paragraph brings within the purview of the Brussels I Recast judgments of the courts of the Member States given on the substance of a dispute in cases where the arbitration agreement has been nullified. It also gives the New York Convention precedence over the Brussels I Recast. The fourth paragraph excludes actions or ancillary proceedings relating to arbitration. ${ }^{16}$ As a result of these novel provisions in the Brussels I Recast, it is, therefore, necessary to fully examine the treatment of arbitration under the new EU legislative framework in order to ascertain the extent of the arbitration exclusion contained therein. This is, of course, important to the EU internal market as the constant expansion of international commercial transactions requires robust legal regimes for the effective settlement of disputes within the EU and the smooth recognition and enforcement of decisions of the courts of the EU Member States and arbitral tribunals. ${ }^{17}$

In considering the present and probable future of commercial arbitration in the EU, it is argued in this book that even though it is difficult to predict the

13 Case C-103/05 Reisch Montage AG v Kiesel Baumaschinen Handel GmbH [2006] ECLI:EU:C:2006:471, para 22; Case C-406/09 Realchemie Nederland BV v Bayer CropScience AG [2011] ECLI:EU:C:2011:668, para 38; Case C-167/08 Draka NK Cables and Others [2009] ECLI:EU:C:2009:263, para 20; Case C-292/08 German Graphics Graphische Maschinen [2009] ECLI:EU:C:2009:544, para 27.

14 For instance, in Case C-536/13 Gazprom v Lithuania [2015] ECLI:EU:C:2015: 316 , the CJEU in its recent decision on the scope of the arbitration exclusion referred to its previous decisions in the Marc Rich and West Tankers cases.

15 Brussels I Recast (n 5) Art 1(2)(d) and recital 12; Trevor Hartley, 'Choice of Court Agreements and the New Brussels I Regulation' (2013) LQR 309, 312; Hartley, 'The Brussels I Regulation' (n 12) 861.

16 Brussels I Recast (n 5) recital 12.

17 James Fry, 'Désordre Public International under the New York Convention: Wither Truly International Public Policy’ (2009) Chinese JIL 81, 82. 
long-term impact of Brexit on international arbitration, one could reasonably conclude, on the basis of the current facts, that Brexit will have no major impact on London's arbitration status as the regulation of arbitration is entirely dependent on national and international arbitration laws. In addition, it is also argued that the new provisions of the Brussels I Recast on arbitration fare better than its predecessors (Art 1(4) of the Brussels Convention and Art 1(2) (d) of the Brussels I Regulation) as recital 12 of the Brussels I Recast provides greater clarity in relation to the scope of the arbitration exclusion in Art 1(2) (d) of the Brussels I Recast. Notwithstanding the commendable clarifications introduced by the new recital 12 of the Brussels I Recast, the recital does not resolve all the questions concerning the arbitration/litigation interface. Recital 12 of the Brussels I Recast does not prevent parallel court/arbitration proceedings on arbitration-related matters, either between two EU Member States' courts or between a court of a Member State and an arbitral tribunal. Indeed, the inability of the EU legislators to address the problem of parallel court/ arbitration proceedings and the potential risk of inconsistent decisions in the Brussels I Recast is not acceptable as it does not encourage the free movement of decisions within the EU; nor does it satisfactorily address the arbitration/litigation interface within the EU. One could rightly agree that parallel proceedings are undesirable as they may cause legal uncertainty, delay in the dispute resolution process, extra cost and the risk of inconsistent decisions. Surely, the functioning of the internal market and the free circulation of decisions within the EU would be improved if the problem of the arbitration/litigation interface were satisfactorily addressed at the EU level, because the EU Member States cannot unilaterally amend the provisions of the New York Convention to address the arbitration/litigation interface at the international level, nor is there a consensus amongst the Contracting States of the New York Convention to revise the provisions of the Convention in order to address this problem. ${ }^{18}$

It is important to point out from the outset that there were concerns by some of the EU Member States that the inclusion of arbitration within the material

18 Gabrielle Kaufmann-Kohler, 'How to Handle Parallel Proceedings: A Practical Approach to Issues Such as Competence-Competence and Anti-suit Injunctions' (2008) Dispute Resolution International 110, 113; Albert Jan van den Berg, 'Hypothetical Draft Convention on International Enforcement of Arbitration Agreements and Awards: Explanatory Note' in Albert Jan van den Berg (ed) 50 Years of the New York Convention: ICCA International Arbitration Conference, ICCA Congress Series (Kluwer Law International 2009) 649-666; Albert Jan van den Berg, The New York Arbitration Convention of 1958: Towards a Uniform Judicial Interpretation (Kluwer Law and Taxation Publishers 1981) 2; Pieter Sanders, 'The History of the New York Convention' in Albert Jan van den Berg (ed) Improving the Efficiency of Arbitration Agreements and Awards: 40 Years of Application of the New York Convention, ICCA Congress Series (Kluwer Law International 1999) 11, 12. 
scope of the Brussels I Regime could create the exclusive external competence of the EU in aspects of international commercial arbitration. Although EU exclusive external actions could positively impact on the development of internal legislation which could be relevant to the functioning of the internal market, the Member States are very reluctant to give the European Commission the power to intervene on their behalf on any matters concerning commercial arbitration because they do not wish to lose their external competence on this point. This is because exclusive external competence of the EU in aspects of international commercial arbitration could limit the powers of the Member States to adopt arbitration instruments and it may also encourage the harmonisation of arbitration in the EU, which some of the Member States strongly oppose. ${ }^{19}$ Whilst it could be argued that the harmonisation of arbitration within the EU could provide certainty as the harmonised arbitration instrument will operate to coordinate the jurisdiction of arbitral tribunals and courts of the EU Member States, thereby addressing the arbitration/litigation interface at the EU level, it could equally be argued that the harmonisation of arbitration within the EU could stifle competition amongst the EU arbitration centres.

Currently, the law and practice of arbitration across the EU Member States is not harmonised and the practice of arbitration within the EU has, over the years, developed on the basis of the New York Convention and the national arbitration laws of the Member States, even though difficulties still exist with regard to the interaction of arbitration and court litigation in the EU. ${ }^{20}$ Therefore, the relevant question is what should be done? Should the problem of the EU arbitration/litigation interface be left unresolved or should a solution be devised to resolve it? The suggested solution in this book is to introduce changes on the point of arbitration in any future revision of the Brussels I Recast that could alleviate the arbitration/litigation interface without creating the exclusive external competence of the EU in aspects of international commercial arbitration and/or interfering with the operation of the New York Convention within the EU. In other words, any future revision of the arbitration exclusion in the Brussels I Regime in the EU must guarantee as a minimum (1) the protection of the principle of party autonomy, (2) the legal certainty in the arbitral process, (3) the competence of the Member States to regulate their national arbitration and (4) the continuous and the smooth functioning of the New York Convention. The justification for the suggested solution is that the

19 Green Paper on the review of Council Regulation (EC) No 44/2001 on jurisdiction and the recognition and enforcement of judgments in civil and commercial matters [2009] COM (2009) 175 final (hereinafter 'Green Paper') 1; see the different views on the Green Paper [http://ec.europa.eu/justice/newsroom/civil/opinion/090630_en.htm] accessed 31 October 2014.

20 Impact Assessment (n 2) 34. 
effectiveness of international commercial arbitration in the EU could improve the free movement of decisions within the EU, which is, of course, necessary for the proper functioning of the EU internal market.

\subsection{BREXIT AND INTERNATIONAL COMMERCIAL ARBITRATION}

The question that readily comes to mind in the field of arbitration in the UK following the decision by the UK to leave the EU is how will Brexit impact arbitration in the UK? It should be recalled that in 2013, the then UK Prime Minister, David Cameron, promised an 'In/Out' referendum on the UK's membership of the EU before the end of 2017, which would be followed by a period of negotiation for the UK's withdrawal from the EU in the event the UK voted to leave the EU. The referendum took place on 23 June 2016 and the UK voted to leave the EU. This is the first time a Member State of the EU has voted to leave the Union and the first time the Article 50 Treaty on European Union (TEU) procedure has been used by a Member State. ${ }^{21}$

21 Art 50 TEU sets out the procedure for a Member State to withdraw its membership of the EU. It provides that '(1) Any Member State may decide to withdraw from the Union in accordance with its own constitutional requirements. (2) A Member State which decides to withdraw shall notify the European Council of its intention. In the light of the guidelines provided by the European Council, the Union shall negotiate and conclude an agreement with that State, setting out the arrangements for its withdrawal, taking account of the framework for its future relationship with the Union. That agreement shall be negotiated in accordance with Article 218(3) of the Treaty on the Functioning of the European Union. It shall be concluded on behalf of the Union by the Council, acting by a qualified majority, after obtaining the consent of the European Parliament. (3) The Treaties shall cease to apply to the State in question from the date of entry into force of the withdrawal agreement or, failing that, two years after the notification referred to in paragraph 2, unless the European Council, in agreement with the Member State concerned, unanimously decides to extend this period. (4) For the purposes of paragraphs 2 and 3, the member of the European Council or of the Council representing the withdrawing Member State shall not participate in the discussions of the European Council or Council or in decisions concerning it. A qualified majority shall be defined in accordance with Article 238(3)(b) of the Treaty on the Functioning of the European Union. (5) If a State which has withdrawn from the Union asks to rejoin, its request shall be subject to the procedure referred to in Article 49.' See generally: HM Government, The Process for Withdrawing from the European Union [https://www .gov.uk/government/uploads/system/uploads/attachment_data/file/503908/54538_EU Series No2 Accessible.pdf] accessed 30 June 2016; Report of the House of Lord's European Union Select Committee, The Process of Withdrawing from the European Union (11th Report of Session 2015-16 - published 4 May 2016 - HL Paper 138) [http://www.publications.parliament.uk/pa/ld201516/ldselect/ldeucom/138/13802 
The former UK Prime Minister, Theresa May, made it clear that 'Brexit means Brexit', and Art 50 TEU was triggered in March 2017, which would allow a two-year period of negotiation between the UK and the EU. ${ }^{22}$ The significant implication of triggering Art 50 was that the UK's membership of the EU, which had existed since January 1973 following the signing of the Treaty of Accession 1972 by the then UK Prime Minister, Edward Heath, was scheduled to end on 29 March 2019 unless the period was extended by a unanimous decision of the European Council, in agreement with the UK. There were several extensions as the UK Parliament rejected the UK-EU deal negotiated by Theresa May. This resulted in a change of Conservative Party leadership as well as a general election that saw the Conservative Party gain the majority seats in the Parliament, with Boris Johnson as the new Prime Minister.

Although the UK officially exited the EU on 31 January 2020 after 47 years of membership, and more than three years after it voted to do so in the referendum, the UK will continue to follow all the EU's rules and regulations, with the UK remaining in the single market and the customs union, and the free movement of people continuing, until 31 December 2020. At the time of writing, it is still not entirely clear what the outcome of the negotiation between the EU and the UK will be in terms of their future relationship beyond the end of 2020; nor is it clear whether London's arbitration status will be affected in the long term. London is regarded as one of the most notable arbitration venues for dispute resolution. The basis for its popularity can be traced to the supportive attitude to, and the role of the national courts in, arbitration; the specialist lawyers and judicial experts in the field of arbitration; the robust legal framework on arbitration (Arbitration Act 1996); and the fact that London is considered to be a global commercial hub whose impact transcends the shores of Europe. However, Brexit seems to have cast a shadow of doubt on London's arbitration status. Indeed, commercial actors choosing arbitration as a method for resolving any potential dispute(s) in their commercial transaction would

.htm] accessed 30 June 2016; Andrew Dickinson, 'Back to the Future: the UK's EU Exit and the Conflict of Laws' (2016) Journal of Private International Law 195-210.

22 The decision by the UK government to trigger Art 50 was controversial and was challenged before the UK courts. $R$ (on the application of Miller) $v$ Secretary of State for Exiting the European Union (Divisional Court) [2017] 1 CMLR 34, (Supreme Court) [2018] AC 61, [2017] 2 WLR 583. The main question before the court was whether the decision to trigger Art 50 TEU by giving notice of the UK's withdrawal from the EU was one for the UK government using the Crown's prerogative or one for the UK Parliament through the statute. Indeed, this raised important constitutional issues particularly in relation to Parliamentary sovereignty and the powers of the UK government under the Crown. The UK Supreme Court, however, concluded that the UK government cannot trigger Art 50 TEU without an authorising Act of the UK Parliament. 
want to know the potential impact of choosing English law as the governing law as well as London as their seat of arbitration in the wake of the Brexit saga.

Currently, commercial arbitration is excluded from the EU legal framework on jurisdiction, the Brussels I Regime. Over the years, the practice of arbitration within the Member States of the EU has been regulated by the national arbitration laws of the Member States and other international instruments on arbitration such as the New York Convention. This means that EU law does not regulate any commercial arbitration issues such as the commencement of arbitration proceedings (for example, appointment of arbitrators), the powers and jurisdiction of the arbitrators, preliminary issues relating to the existence and validity of arbitration agreements, ancillary proceedings in support of arbitration, application for interim measures, the recognition and enforcement of arbitral awards, and court proceedings for the annulment of arbitral awards.

Therefore, even though there may be challenges in the future relationship between the UK and the EU, which depends largely on the outcome of the negotiations between the UK government and the EU, it appears that Brexit will have no major adverse impact on London's arbitration status as UK national arbitration laws and the New York Convention will continue to be applicable. In other words, where commercial parties choose London as their seat of arbitration as well as English law (including choosing the Arbitration Act 1996) to govern the resolution of their dispute, the English courts will continue to recognise and give effect to the autonomy of the parties to regulate their dispute resolution process post-Brexit. In addition, arbitral awards delivered in the UK will continue to be recognised and enforced across the globe by the Contracting States of the New York Convention post-Brexit. Likewise, the UK courts will continue to recognise and enforce foreign arbitral awards in accordance with the UK legal framework on arbitration and the New York Convention.

Furthermore, as a result of Brexit, the UK court or tribunal will no longer be 'bound by any principles laid down, or any decisions made, on or after exit day by the European Court'. Nor can a court or tribunal of the UK refer any matter 'to the European Court on or after exit day'. ${ }^{23}$ The UK Supreme Court, the High Court (sitting on appeal) or any other relevant court or tribunal designated by a Minister of the Crown will no longer be bound by any retained EU law. ${ }^{24}$ This means that the above-mentioned courts may depart from any retained EU case law including reversing the CJEU decision prohibiting the grant of anti-suit injunctions in favour of choice of court/arbitration agree-

23 European Union (Withdrawal) Act 2018, section 6(a) and (b).

24 European Union (Withdrawal) Act 2018, section 6(4)(a), (b) and (c). European Union (Withdrawal Agreement) Act 2020, section 26. 
ments. This will, of course, be to the advantage of UK arbitration centres as the UK courts will be capable of granting anti-suit injunctions restraining parties from acting in breach of the arbitration agreements regardless of the domicile of the parties, thus maintaining its competitive advantage over other EU arbitration centres as well as competing with other non-EU arbitration centres such as New York, Bermuda and Singapore, which equally exercise the jurisdiction to grant anti-suit injunction in support of arbitration. In addition, the UK will continue to retain its competence in arbitration post-Brexit, and thus to regulate the conduct of the arbitration proceedings to suit commercial parties wishing to arbitrate within the UK. Although other EU Member States have external competence in commercial arbitration, this position may change in the future should arbitration be regulated under the Brussels I Regime without express clarification of the scope of the EU external competence on arbitration in the Treaties. However, in deciding whether to depart from any retained EU case law, the UK 'Supreme Court or the High Court of Justiciary must apply the same test as it would apply in deciding whether to depart from its own case law' or a Minister of the Crown may by regulation provide the 'test which a relevant court or relevant tribunal must apply in deciding whether to depart from any retained EU case law'. ${ }^{25}$

It is also necessary to point out at the outset that the obligation for the mutual recognition and enforcement of judgments in civil and commercial matters between the UK courts and other Member States' courts may no longer apply following the UK's exit from the EU, but the correct position will depend largely on the final outcome of the negotiation between the UK government and the EU. Finally, in the process of analysing the interaction of court litigation and arbitration in this book, any potential impact of Brexit on international arbitration will be highlighted in the relevant section and a more detailed analysis provided accordingly.

\subsection{THE STRUCTURE OF THE BOOK}

The examination of the issues in this book is divided into eight chapters. This introductory chapter delineates the aims and objectives of this book. It provides a brief account of Brexit and the EU arbitration/litigation problems as well as the legislative history of the Brussels I Recast. Chapter 2 explores the impact of Brexit on the mutual recognition and enforcement of judgments under the Brussels I Regime. The chapter also examines the concept of mutual trust in the context of international commercial arbitration by tracing the

25 European Union (Withdrawal) Act 2018, section 6(5). European Union (Withdrawal Agreement) Act 2020, section 26. 
link between EU law and international commercial arbitration. In Chapter 3 , the scope of the arbitration exclusion under the Brussels I Regime is fully explored, as well as the CJEU case law in this area and the divergent views on the application of the arbitration exclusion. Chapter 4 examines whether there are effective procedural mechanisms that may be used to prevent parallel court/arbitration proceedings and the risk of conflicts between arbitral awards and judgments of the Member States' courts, thus alleviating the arbitration/ litigation interface. Chapter 5 looks at the efforts made by EU legislators to resolve the arbitration/litigation interface. It shows that the need to safeguard the operation of the New York Convention within the EU and to avoid the risk of creating exclusive external competence of the EU in aspects of international arbitration were the two main political reasons why the proposed Art 29(4) of the European Commission's 2010 proposal to recast the Brussels I Regulation was rejected on the point of arbitration. In Chapter 6, the external competence of the EU is examined. The chapter argues that as the law currently stands, the inclusion of arbitration within the material scope of the Brussels I Regime could create the risk of exclusive external competence of the EU in aspects of international commercial arbitration as the CJEU may reach such a conclusion having regard to its case law on the subject. In Chapter 7, the practical effect of the innovative provisions of recital 12 of the Brussels I Recast is analysed. The chapter argues that notwithstanding the commendable clarifications introduced by the Brussels I Recast in relation to the arbitration exclusion, the provision on arbitration in the Brussels I Recast does not completely address the arbitration/litigation interface. Accordingly, there is a need for further reform of the Brussels I Recast on the point of arbitration to eliminate the remaining legal uncertainties in the relationship between arbitration and court litigation in the EU. This could be achieved by the introduction of specific rules to coordinate the jurisdiction of courts and arbitral tribunals in the Brussels I Regime without undermining the operation of the New York Convention and/or creating exclusive external competence of the EU over aspects of international commercial arbitration. Finally, Chapter 8 provides the general conclusion of this book.

\subsection{SCOPE AND RELEVANCE}

This book assumes a basic understanding of the arbitration process and is devoted to an analysis of the potential impact of Brexit on international arbitration in the UK as well as an analysis of the interaction of commercial arbitration and the EU Brussels I Regime. ${ }^{26}$ It is true that the interaction of EU

26 For academic commentary on the process of arbitration, see generally: Nigel Blackaby and Constantine Partasides with Alan Redfern and Martin Hunter, Redfern 
law and arbitration could also be seen in other arbitration areas, such as EU law and investor-State arbitration, EU law and consumer arbitration, the interaction of the Rome I and Rome II Regulations in commercial arbitration, and human rights and arbitration. ${ }^{27}$ However, the scope of this book is limited to the treatment of arbitration under the Brussels I Regime as well as the potential impact of Brexit on commercial arbitration.

The relevance of this book is underscored by the growing implications of cross-border transactions and the need to safeguard the practice of commercial arbitration in the UK and the EU. ${ }^{28}$ In today's economic reality, the potential for commercial parties to contract gives rise to possible dispute between the parties, and the manner in which the parties resolve their dispute is essential to their continued contractual relationship. Empirical research has shown that the majority of large European corporations, commercial actors and non-European domiciled businesses prefer arbitration over court litigation to resolve their disputes, and where they have a choice, they prefer to arbitrate within the EU. ${ }^{29}$ The use of commercial arbitration as the preferred dispute resolution method is continuing to increase and the notable European arbitration venues, such as the International Chamber of Commerce (ICC) in France, the London Court of International Arbitration (LCIA) in England and the Stockholm Chamber of Commerce (SCC) in Sweden, continue to generate significant revenue as commercial parties often choose them as seat of arbitration.

In 2013, the ICC International Court of Arbitration received 767 requests for commencement of an arbitration, the London Court of International Arbitration received 301, the Stockholm Chamber of Commerce received 203 and the German Institution of Arbitration received 121. These were often disputes of considerable importance: 540 of the cases the ICC received in 2013 involved a dispute worth

and Hunter on International Arbitration (6th edn, OUP 2015); Emmanuel Gaillard and John Savage (eds) Fouchard Gaillard Goldman on International Commercial Arbitration (Kluwer Law International 1999); Gary Born, International Commercial Arbitration (Kluwer Law International 2009); Julian DM Lew, Loukas A Mistelis and Stefan M Kröll, Comparative International Commercial Arbitration (Kluwer Law International 2003).

27 Chukwudi Paschal Ojiegbe, 'The Impact of EU Law on International Commercial Arbitration' (2019) EdinbLR 140; Franco Ferrari, The Impact of EU Law on International Commercial Arbitration (Juris Publishing 2017).

${ }_{28}$ Will Hueske, 'Rule, Britannia! A Proposed Revival of the British Antisuit Injunction in the EU Legal Framework' (2009) GWashIntlLRev 433; Douglas Reichert, 'Problems with Parallel and Duplicate Proceedings: The Litispendence Principle and International Arbitration' (1992) ArbIntl 237.

29 Surveys show that about 63 per cent of large European companies prefer arbitration over litigation to resolve their business disputes. See generally: Impact Assessment (n 2) 35 . 
more than US\$1m, 277 more than US\$10m, and 63 more than US\$100m. Yet these numbers represent only a fraction of the arbitrations occurring each year, with many more arbitral institutions operating in Europe, and a large number of arbitrations occurring without the involvement of an institution. ${ }^{30}$

In 2009, the European Commission stated that the European arbitration centres administered 4,453 international arbitration cases with a total value of over $€ 50$ billion, and that figure was set to rise. ${ }^{31}$ Surely, arbitration remains a significant factor in commercial transactions and is of significant economic importance for the EU. Notwithstanding the significant economic impact arbitration has in the EU, the European arbitration industry continues to face increasing competition from other leading non-European arbitration centres such as New York, Singapore, Dubai, Hong Kong and China, hence the need to encourage effective legal regimes for the settlement of commercial disputes within the EU. ${ }^{32}$ The supportive roles of the national courts of the EU Member States in the arbitral process and how well the legal framework on arbitration functions in the EU are indeed important to the successful operation of international commercial arbitration within the EU. Therefore, exploring the potential implications of Brexit on commercial arbitration in the UK as well as addressing the arbitration/litigation interface and safeguarding the effectiveness of arbitration within the EU by eliminating any legal uncertainties in the EU dispute resolution process will improve the attractiveness of the EU arbitration centres as seats of international arbitration.

Accordingly, this book provides useful guidance on the potential impact of Brexit on commercial arbitration as well as the interpretation of the novel provisions contained in recital 12 of the Brussels I Recast, thereby contributing to a more fulsome understanding of the rationale behind the innovative provisions. It assesses the legislative history of the Brussels I Recast and the debates on the EU arbitration/litigation interface, and it considers whether the Brussels I Recast has resolved the problem. It also considers the risks of including arbitration within the material scope of the Brussels I Regime and the consequences for EU exclusive external competence in aspects of international commercial arbitration. Finally, the book contributes to the knowledge of law by exploring what is currently contained in the Brussels I Recast and

30 Tony Cole, ESRC funded project on 'The Social and Psychological Underpinnings of Commercial Arbitration in Europe' [https://gtr.ukri.org/projects?ref= ES\%2FR005664\%2F1] accessed 24 July 2018.

31 The total value of the arbitration industry in the EU was estimated in 2009 at $€ 4$ billion with the tendency for the figure to continue growing. See generally: Impact Assessment (n 2) 36 .

32 Fry (n 17) 82; UNCITRAL Model Law on International Commercial Conciliation with Guide to Enactment and Use 2002. 
provides novel solutions that could be made on the point of arbitration in any future reform of the Brussels I Recast.

\subsection{AN HISTORICAL BACKGROUND TO THE EU ARBITRATION/LITIGATION INTERFACE}

It is imperative to provide a brief historical background to the EU arbitration/ litigation interface in order to inform the discussion in this book. The practical significance of tracing the history in brief is to show that the problem of the EU arbitration/litigation interface is a longstanding one that has appeared intractable. Accordingly, this section seeks to provide a brief historical account, and the arguments on the EU arbitration/litigation interface will be fully developed later.

In 1958, the Treaty of Rome, officially the Treaty establishing the European Economic Community (TEEC), came into force. ${ }^{33}$ Art 220 of the Treaty provides that the Member States of the EEC (now 'EU'):

... shall, so far as is necessary, enter into negotiations with each other with a view to securing for the benefit of their nationals ... the simplification of formalities governing the reciprocal recognition and enforcement of judgments of courts or tribunals and of arbitration awards. ${ }^{34}$

It was on this basis that the Brussels Convention was promulgated in 1968 . The Brussels Convention was enacted in order to unify the rules of conflict of jurisdiction in civil and commercial matters and also to simplify the formalities with a view to rapid and simple recognition and enforcement of judgments from the EU Member States. ${ }^{35}$ The Brussels Convention distributes jurisdiction to the courts of the EU Member States in civil and commercial matters and, in matters falling within its material scope, views the courts of the Member States as a single judicial system. ${ }^{36}$

33 Treaty establishing the European Community (TEEC) 1958 (hereinafter 'Treaty of Rome'); The Treaty of Rome was originally signed by the six Member States (France, Belgium, Italy, Netherlands, Luxembourg and West Germany) on 25 March 1957 and came into force on 1 January 1958.

34 Ibid, Art 220.

35 See the preamble to the Brussels Convention.

36 Markus Lenenbach, 'Antisuit Injunction in England, Germany and the United States: Their Treatment under European Civil Procedure and the Hague Convention' (1998) LoyLAIntl\&CompLRev 257, 307; Chukwudi Paschal Ojiegbe, 'Choice of Court Agreements and Brussels I Recast - The End of “Torpedo" Actions' (2014) TCLR 126. 
On the other hand, the New York Convention, which is the main international instrument on arbitration, had already been in force since 7 June 1959. Notwithstanding the express mention of arbitration and the subsequent recognition and enforcement of arbitral awards in Art 220 of the Treaty of Rome, the Brussels Convention excluded arbitration from its scope by virtue of Art 1(4). The Committee of Experts that drafted the Brussels Convention clearly stated that arbitration was excluded because there were many existing international instruments on arbitration and, in particular, the New York Convention. ${ }^{37}$ From the text of Art 1(4) of the Brussels Convention, it was not particularly clear at that time what aspects of arbitration were excluded from its scope of application. ${ }^{38}$ For instance, arbitration includes amongst other things the commencement of arbitration proceedings (for example, appointment of arbitrators), the powers and jurisdiction of the arbitrators, preliminary issues relating to the existence and validity of arbitration agreements, ancillary proceedings in support of arbitration, application for interim measures, the recognition and enforcement of arbitral awards, and court proceedings for the annulment of arbitral awards. It is arguable that all these arbitration-related matters are excluded from the material scope of the Brussels Convention, but equally arguable that some of them are not excluded from the Convention. Indeed, the practical significance of clarifying the scope of the arbitration exclusion in the Brussels Convention is to delineate the extent of the jurisdiction of the courts of the Member States in arbitration proceedings covered by arbitration instruments (for example, the New York Convention and national arbitration laws of the Member States) and court proceedings in civil and commercial matters covered by the Brussels Convention. It follows that since most commercial disputes that could be resolved by arbitration may equally be resolved by the courts of the Member States, it was important at the time to clarify the scope of the arbitration exclusion in order to properly outline the extent of the courts of the Member States jurisdiction under the Brussels Convention.

The problem with the lack of clarity in the arbitration exclusion manifested when Denmark, Ireland and the UK acceded to the Brussels Convention. ${ }^{39}$ In particular, two divergent positions which were irreconcilable emerged in the Schlosser Report. On the one hand, the UK government argued that the arbi-

37 Report on the Convention on jurisdiction and the enforcement of judgments in civil and commercial matters [1979] OJ C59/1 (hereinafter 'Jenard Report') 13.

38 Kaye, 'The Judgments Convention and Arbitration' (n 4) 289.

39 Report on the Convention on the Association of the Kingdom of Denmark, Ireland and the United Kingdom of Great Britain and Northern Ireland to the Convention on jurisdiction and the enforcement of judgments in civil and commercial matters and to the Protocol on its interpretation by the Court of Justice [1979] OJ C59/71 (hereinafter 'Schlosser Report') para 61. 
tration exclusion covers all disputes which the parties agreed to be settled by arbitration. In contrast, the original Member States argued that the arbitration exclusion covers only proceedings before national courts if they referred to arbitration proceedings. ${ }^{40}$ The Schlosser Report did not clarify the position that was preferred but stated that no amendment should be made to the text of the arbitration exclusion and that the new Member States could deal with this problem of interpretation in their implementing legislation. ${ }^{41}$ This view seems somewhat problematic as it tends to suggest that the new Member States may adopt a different approach in the interpretation of the scope of the arbitration exclusion in their implementing legislation. The problem with this view is that the Brussels Convention is distinct from the domestic legislation of the Member States. ${ }^{42}$ Rather, the Brussels Convention is a harmonised private international law instrument that is uniformly interpreted and applied amongst the courts of the Member States. Thus, the possibility of having different interpretations on the scope of the arbitration exclusion due to its lack of clarity may harm the uniformity which the Brussels Convention seeks to ensure. It follows that the lack of express clarification concerning which aspects of arbitration are excluded from the scope of the Brussels Convention led to the complexity and uncertainty in applying and/or interpreting the scope of the arbitration exclusion in the Brussels I Regime. ${ }^{43}$

The CJEU was given the opportunity to clarify the scope of the arbitration exclusion in the Marc Rich and Van Uden cases. ${ }^{44}$ In its decision in the Marc Rich case, the CJEU held that the arbitration exclusion in the Brussels Convention covers proceedings pending before the court of a Member State concerning the appointment of arbitrators. ${ }^{45}$ An interesting aspect of the CJEU's decision is the fact that the Court clarified that it is the subject matter of a dispute that determines whether such a dispute falls within the scope of

$40 \quad$ Ibid, para 61.

41 Ibid, para 61.

42 Hans van Houtte, 'Why Not Include Arbitration in the Brussels Jurisdiction Regulation' (2005) ArbIntl 509, 512.

43 See the following cases: Case C-190/89 Marc Rich (n 4); Case C-391/95 Van Uden Maritime (n 4); Case C-185/07 West Tankers (n 4); Partenreederei M/S and Others v Grosvenor Grain and Feed Co Ltd and Others (The 'Heidberg') [1994] 2 Lloyd's Rep 287; Navigation Maritime Bulgare v Rustal Trading Ltd and Others (The 'Ivan Zagubanski') [2002] 1 Lloyd's Rep 107; Through Transport Mutual Insurance Association (Eurasia) Ltd v New India Assurance Association Co Ltd [2004] 2 CLC 1189; National Navigation Co v Endesa Generacion SA (The Wadi Sudr) [2010] 2 All ER (Comm) 1243.

44 Case C-190/89 Marc Rich (n 4); Case C-391/95 Van Uden Maritime (n 4).

45 Case C-190/89 Marc Rich (n 4) para 31. 
the Brussels Convention. ${ }^{46}$ Does this mean that once the subject matter of the dispute falls within the material scope of the Brussels Convention, preliminary issues (regardless of whether it is an arbitration-related court proceeding) also come within the scope of the Brussels Convention? In the Van Uden case, the CJEU ruled that the issue whether an interim measure is covered by the arbitration exclusion in Art 1(4) of the Brussels Convention depends on the nature of the protected right rather than on the nature of the interim measure, since an interim measure is usually parallel and not ancillary to arbitration proceedings.$^{47}$ In that regard, the CJEU concluded that where the subject matter of the dispute falls within the scope of the Brussels Convention, the courts of the Member States may grant provisional measures 'even where proceedings have already been, or may be, commenced on the substance of the case and even where those proceedings are to be conducted before arbitrators' ${ }^{48}$ The decisions of the CJEU in the Marc Rich and Van Uden cases left several questions unanswered. ${ }^{49}$ For instance, it was not particularly clear at the time what the position was regarding the judgments of the courts of the Member States on the existence and validity of arbitration agreements and judgments on the substance of the dispute where the arbitration agreement has been nullified. ${ }^{50}$ It remained uncertain whether these judgments fall within the scope of the Brussels Convention. ${ }^{51}$

When the Brussels I Regulation was adopted, it retained the arbitration exclusion in Art 1(2)(d). The Brussels I Regulation did not fundamentally change the objectives and structure of the rules of the Brussels Convention, but it amended and introduced some new provisions in the existing rules. ${ }^{52} \mathrm{In}$ 2009, the CJEU delivered its decision in the infamous West Tankers case. ${ }^{53}$ The Court expanded the scope of the Brussels I Regulation in the West

$46 \quad$ Ibid, para 26; Jenard Report (n 37) 10.

47 Case C-391/95 Van Uden Maritime (n 4) para 33; Andrea Estrup Ippolito and Morten Adler-Nissen, 'West Tankers Revisited: Has the New Brussels I Regulation Brought Anti-suit Injunctions Back into the Procedural Armoury' (2013) Arbitration 158, 161; Martin Illmer and Ingrid Naumann, 'Yet Another Blow: Anti-suit Injunctions in Support of Arbitration Agreements within the European Union' (2007) IntALR 147, 150.

Case C-391/95 Van Uden Maritime (n 4) para 34.

Beraudo (n 4) 16.

Ambrose (n 4) 13.

Hascher (n 4) 56.

52 Janeen Carruthers, 'The Brussels I Regulation Recast' (2011) SLT 31. Following the coming into force of the Treaty of Amsterdam in 1999, private international law matters were integrated within the first pillar of European Community law. As a direct result of this development, the Brussels Convention was converted into the Brussels I Regulation which directly applied to all the Member States.

53 C-185/07 West Tankers (n 4). 
Tankers case when it held that preliminary proceedings on the existence and validity of arbitration agreements fall within the material scope of the Brussels I Regulation. ${ }^{54}$ The CJEU also prohibited the grant of anti-suit injunctions as they were deemed by the Court to be incompatible with the scheme of the Brussels I Regulation. ${ }^{55}$ It should be noted that the CJEU had earlier prohibited the grant of anti-suit injunctions between the Member States on matters falling within the material scope of the Brussels I Regime, ${ }^{56}$ but the Court left open an important question on whether anti-suit injunctions granted in support of arbitration (which fell outside the scope of the Brussels I Regime) were compatible with the Brussels I Regulation. In that regard, the English courts continued to grant anti-suit injunctions in support of arbitration on the ground that arbitration fell outside the material scope of the Brussels I Regulation. ${ }^{57}$

However, in its decision in the West Tankers case, the CJEU found that the Brussels I Regulation prohibited the grant of an anti-suit injunction in support of arbitration. ${ }^{58}$ The Court's decision on the applicability of the Brussels I Regulation to preliminary issues relating to the scope of arbitration agreements was criticised on the ground that parties may devise means to circumvent an arbitration agreement by commencing proceedings in an EU Member State's court in which they believe they would be most likely to obtain a decision that the arbitration agreement is not applicable and any decision by that court on the existence and validity of the arbitration agreement would circulate within the EU. ${ }^{59}$ The decision highlighted the significant challenges international commercial arbitration faced in the EU, such as parallel proceedings and irreconcilable decisions between courts and arbitral tribunals where the arbitration agreement is held invalid in one Member State and valid in another. ${ }^{60}$ Likewise, it could equally be said that the decision 'raised concerns within the

\footnotetext{
54 Ibid, para 26.

$55 \quad$ Ibid, para 35.

56 Case C-159/02 Turner v Grovit (n 9).

57 Through Transport (n 43); West Tankers Inc v Ras Riunione Adriatica Di Sicurta

(The 'Front Comor') [2005] 2 Lloyd's Rep 257.

58 C-185/07 West Tankers (n 4) para 35.

59 Andrew Pullen, 'The Future of International Arbitration in Europe: West Tankers and the EU Green Paper' (2009) IntALR 56; Stuart Dutson and Mark Howarth, 'After West Tankers - Rise of the "Foreign Torpedo"?' (2009) Arbitration 334, 338; Hakeem Seriki, 'Anti-suit Injunctions, Arbitration and the ECJ: An Approach Too Far?' (2010) JBL 24; Kyriaki Noussia, 'Antisuit Injunctions and Arbitration Proceedings: What Does the Future Hold?' (2009) JIntlArb 311, 333; Louise Hauberg Wilhelmsen, 'The Recast Brussels I Regulation and Arbitration: Revisited or Revised?' (2014) ArbIntl 169.

${ }^{60}$ European Commission Staff Working Paper (Impact Assessment) Accompanying document to the
} 
arbitration community regarding tensions between EU law and international arbitration and namely that European courts might limit the principle of party autonomy, one of the cornerstones of arbitration' ${ }^{61}$

Applying the ratio decidendi of the West Tankers case, the English Court of Appeal in 'The Wadi Sudr' case ${ }^{62}$ felt compelled to recognise the judgment of a Spanish court that an arbitration clause had not been incorporated in the contract. The English Court of Appeal held that the judgment of the Spanish court fell within the scope of the Brussels I Regulation and, as such, on the basis of issue estoppel, was subject to recognition by the English Court regardless of its own (differing) views on, and practice concerning, the question of such incorporation. ${ }^{63}$ This showed the effect of the CJEU decision in the West Tankers case, particularly on the interface between court litigation under the Brussels I Regulation and arbitration proceedings in the EU, which, of course, had serious practical implications on the options available to a contracting party faced with the blatant disregard of an arbitration agreement. ${ }^{64}$ It follows that there may be possible conflict between the international obligations of the Member States to give effect to arbitration agreements under the New York Convention and their obligations under the Brussels I Regime to recognise and enforce judgments in civil and commercial matters. ${ }^{65}$

\subsection{ADDRESSING THE EU ARBITRATION/ LITIGATION INTERFACE}

Following on from the problems highlighted in the preceding section, it is also important to set out from the outset the legislative history of the EU legislators' efforts to address the arbitration/litigation interface. The CJEU decision in the

Proposal for a Regulation of the European Parliament and of the Council on jurisdiction and the recognition and enforcement of judgments in civil and commercial matters (Recast) SEC [2010] 1547 final 35 (hereinafter 'Impact Assessment').

${ }_{61}$ A study on the Legal Instruments and Practice of Arbitration in the EU requested by the Committee on Legal Affairs (PE 509.988 EN) 190.

62 National Navigation Co v Endesa Generacion SA (The Wadi Sudr) [2010] 2 All ER (Comm) 1243.

${ }_{63}$ Ibid; Yvonne Baatz, 'A Jurisdiction Race in the Dark: The Wadi Sudr' (2010) Lloyds Maritime and Commercial Law Quarterly 364-375; Paul Beaumont and Emma Johnston, 'Can Exequatur Be Abolished in Brussels I whilst Retaining a Public Policy Defence?' (2010) Journal of Private International Law 249, 267.

${ }^{64}$ Stuart Dutson and Mark Howarth, 'National Navigation Co v Endesa Generacion SA (The Wadi Sudr): Dead Ahead? West Tankers Sails on in the Court of Appeal in The Wadi Sudr' (2010) Arbitration 374.

65 Christa Roodt, 'Conflicts of Procedure between Courts and Arbitral Tribunals with Particular Reference to the Right of Access to Court' (2011) AfrJIntl\&CompL 236. 
West Tankers case led to a lengthy review process to enhance the effectiveness of arbitration agreements and improve the interface between arbitration and the Brussels I Regulation. Art 73 of the Brussels I Regulation states the procedure for amending the Brussels I Regulation. In particular, it required the European Commission to present to the European Parliament, the Council and the Economic and Social Committee a report on the application of the Brussels I Regulation no later than five years after the entry into force of the Brussels I Regulation, together with a proposal for its adaptation. In accordance with the requirement of Art 73 of the Brussels I Regulation, the European Commission instructed three German Professors (Hess, Pfeiffer and Schlosser) to prepare a report on the application of the Brussels I Regulation and make necessary recommendations for its improvement. The team produced the Heidelberg Report ${ }^{66}$ which was published in 2007 before the CJEU's decision in the West Tankers case. ${ }^{67}$ The authors of the Heidelberg Report suggested deleting the arbitration exclusion and inserting a new lis pendens provision in Art 27A that would oblige the courts of the Member States to stay their proceedings in favour of the court of the Member State at the seat of arbitration. ${ }^{68}$

The recommendations contained in the Heidelberg Report provided the basis for the preparation of the European Commission's Report ${ }^{69}$ accompanied by its Green Paper on the review of the Brussels I Regulation. ${ }^{70}$ The suggestions contained in the Green Paper generated many arguments with regard to the contentious relationship between arbitration and the Brussels I Regulation. In particular, it was clear from the public consultation that the majority of the contributors rejected the radical recommendations contained in the Green Paper because it would have brought the regulation of arbitration within the material scope of the Brussels I Regulation. ${ }^{71}$ Against this background, the

66 Burkhard Hess, Thomas Pfeiffer and Peter Schlosser, (JLS/C4/2005/03) Report on the Application of Regulation Brussels I in the Member States, September 2007 (hereinafter 'Heidelberg Report').

${ }_{67}$ Opinion of Advocate General Wathelet in Case C-536/13 Gazprom v Lithuania (n 14) para 94.

${ }_{68}$ Heidelberg Report (n 66) 65, para 134.

69 Report from the Commission to the European Parliament, the Council and the European Economic and Social Committee on the application of Council Regulation (EC) No 44/2001 on jurisdiction and the recognition and enforcement of judgments in civil and commercial matters [2009] COM (2009) 174 final (hereinafter 'European Commission Report').

70 Green Paper on the review of Council Regulation (EC) No 44/2001 on jurisdiction and the recognition and enforcement of judgments in civil and commercial matters [2009] COM (2009) 175 final (hereinafter 'Green Paper').

${ }_{71}$ See the comprehensive list of contributors to the Green Paper [http://ec.europa .eu/justice/newsroom/civil/opinion/090630_en.htm] accessed 31 October 2014. 
European Commission set up an expert group in 2010 which reviewed the arbitration/litigation interface and advised the Commission on the possible ways of resolving the problem. ${ }^{72}$

On the basis of the expert group's advice, the European Commission published its Recast Proposal in $2010^{73}$ accompanied by the Impact Assessment which contained the analysis of the effect of the main aspects of the proposed reform. ${ }^{74}$ In its Impact Assessment, the European Commission indicated three possible options to address the interface between arbitration and court litigation. The first option was to maintain the status quo of the arbitration exclusion in the Brussels I Regulation. The second option was to extend the scope of the arbitration exclusion in the Brussels I Regulation. The third option was to enhance the effectiveness of arbitration agreements within the EU judicial area by inserting a new lis pendens rule in the proposed Art 29(4) that would oblige a court of a Member State seised of a matter in which the parties have made an arbitration agreement to stay proceedings if the arbitral tribunal or the court at the seat of arbitration were seised. ${ }^{75}$ A new Art 33(3) was also inserted in the

72 Martin Illmer, 'Commentary on Art 1 of the Brussels I Regulation Recast' in Andrew Dickinson and Eva Lein (eds) Brussels I Regulation Recast (OUP 2015) 57.

73 Proposal for a Regulation of the European Parliament and of the Council on jurisdiction and the recognition and enforcement of judgments in civil and commercial matters (Recast) [2010] COM (2010) 748 final (hereinafter 'European Commission's Recast Proposal').

74 Impact Assessment (n 2) 35.

75 Ibid, 36-37. For a nuanced commentary on the Commission's proposal, see the following: Opinion of Advocate General Wathelet in Case C-536/13 Gazprom v Lithuania [2015] ECLI:EU:C:2015:316; Jonathan Harris and Eva Lein, 'A Neverending Story? Arbitration and the Brussels I: The Recast' in Eva Lein (ed) The Brussels I Review Proposal Uncovered (British Institute of International and Comparative Law 2012) 38; Pamela Kiesselbach, ‘The Brussels I Proposals - An Overview' in Eva Lein (ed) The Brussels I Review Proposal Uncovered (British Institute of International and Comparative Law 2012); Martin Illmer, 'Brussels I and Arbitration Revisited The European Commission's Proposal COM (2010) 748 final' (2011) RabelsZ 645; Vesna Lazic, 'The Commission's Proposal to Amend the Arbitration Exception in the EC Jurisdiction Regulation: How "Much Ado about Nothing" Can End Up in a "Comedy of Errors" and in Anti-suit Injunctions Brussels-Style' (2012) JIntlArb 19; Luca Radicati di Brozolo, 'Arbitration and the Draft Revised Brussels I Regulation: Seeds of Home Country Control and of Harmonisation?' (2011) Journal of Private International Law 423; Burkhard Hess, 'The Brussels I Regulation: Recent Case Law of the Court of Justice and the Commission's Proposed Recast' (2012) CML Rev 1075; Massimo Benedettelli, "Communitarization" of International Arbitration: A New Spectre Haunting Europe?' (2011) ArbIntl 583; Andrew Dickinson, 'Surveying the Proposed Brussels I bis Regulation - Solid Foundations but Renovation Needed' (2010) Yearbook of Private International Law 247; Peter Arnt Nielsen, 'The State of Play of the Recast of the Brussels I Regulation' (2012) NordicJIL 585. 
European Commission's Recast Proposal to clarify when an arbitral tribunal is seised of a matter. Art 36 of the European Commission's Recast Proposal was amended to allow the courts of the Member States to grant provisional measures even when the courts of other Member States or arbitral tribunals have jurisdiction as to the substance of the matter. The amendment contained in Art 36 of the European Commission Recast Proposal was done in order to bring within the purview of the Brussels I Regulation the decision of the CJEU in the Van Uden case. ${ }^{76}$ It may be recalled that the CJEU held in the Van Uden case that the Member States' courts may grant provisional measures 'even where proceedings have already been, or may be, commenced on the substance of the case and even where those proceedings are to be conducted before arbitrators'. ${ }^{77}$

The Member States' delegations submitted their comments on arbitration. The vast majority of the Member States preferred not to introduce rules that would undermine the smooth operation of the New York Convention by retaining the arbitration exclusion. ${ }^{78}$ Whilst some of the Member States objected to the proposed Art 29(4) of the European Commission's Proposal, ${ }^{79}$ some of the Member States welcomed it as a solution to block torpedo actions and prevent parallel court/arbitration proceedings that may lead to inconsistent decisions. ${ }^{80}$

76 Illmer, 'Commentary on Art 1' (n 72) 58.

77 Case C-391/95 Van Uden Maritime (n 4) para 34.

78 In the comments of the Latvian delegation, most of the Member States supported the exclusion of arbitration from the scope of the draft Regulation in the preliminary discussion (9670/11); see generally, Comments from the Latvian delegation to the Working Party on Civil Law Matters (Brussels I) 9474/11 ADD 12 JUSTCIV 106 CODEC 70015 June 2011.

79 For example, see the following: Comments from the delegation of Cyprus to the Working Party on Civil Law Matters (Brussels I) 9474/11 ADD 11 JUSTCIV 106 CODEC 7002 May 2011; Observations by the Cypriot delegation on Articles 1-34 to the Working Party on Civil Law Matters (Brussels I) 13756/11 ADD 2 JUSTCIV 218 CODEC 13784 October 2011; Comments from the Latvian delegation to the Working Party on Civil Law Matters (Brussels I) 9474/11 ADD 12 JUSTCIV 106 CODEC 700 15 June 2011; Comments from the United Kingdom delegation to the Working Party on Civil Law Matters (Brussels I) 9474/11 ADD 8 JUSTCIV 106 CODEC 7008 June 2011; Comments from the United Kingdom delegation on arbitration to the Working Party on Civil Law Matters (Brussels I) 8035/12 JUSTCIV 118 CODEC 77322 March 2012; Comments from the Polish and French delegations concerning arbitration to the Working Party on Civil Law Matters (Brussels I) 8498/12 JUSTCIV 138 CODEC 911 2 April 2012; Note from the French delegation on arbitration to the Working Party on Civil Law Matters (Brussels I) 6650/12 JUSTCIV 63 CODEC 41921 February 2012; Comments by the Polish delegation to the Working Party on Civil Law Matters (Brussels I) 9474/11 ADD 5 JUSTCIV 106 CODEC 7006 June 2011.

80 Comments from the Lithuanian delegation on arbitration to the Working Party on Civil Law Matters (Brussels I) 8127/12 JUSTCIV 123 CODEC 79926 March 
From the outset, the European Parliament opposed the partial deletion of the arbitration exclusion from the scope of the Brussels I Regime. ${ }^{81}$ Rather, the European Parliament supported the reversal of the West Tankers case by suggesting that 'Article 1(2)(d) of the Regulation should make it clear that not only arbitration proceedings, but also judicial procedures ruling on the validity or extent of arbitral competence as a principal issue or as an incidental or preliminary question, are excluded from the scope of the Regulation.' ${ }^{82}$ The European Parliament further suggested that:

... the various national procedural devices developed to protect arbitral jurisdiction (anti-suit injunctions so long as they are in conformity with free movement of persons and fundamental rights, declaration of validity of an arbitration clause, grant of damages for breach of an arbitration clause, the negative effect of the 'Kompetenz-Kompetenz principle', etc.) must continue to be available and the effect of such procedures and the ensuing court decisions in the other Member States must be left to the law of those Member States as was the position prior to the judgment in Allianz and Generali Assicurazioni Generali. ${ }^{83}$

In its June 2011 Report, the European Parliament, whilst referring to its earlier view in 2010, suggested that 'all aspects of arbitration must be clearly and unambiguously excluded from the scope of the Brussels I Regulation. ${ }^{\prime 84}$ The European Parliament argued that this would be achieved by amending the arbitration exclusion in Art 1(2)(d) of the Brussels I Regulation and introducing a new recital 11 that would confirm that the entire matter of arbitration is excluded from the scope of the Brussels I Regulation. ${ }^{85}$ However, the Danish

2012; Comments by the German delegation to the Working Party on Civil Law Matters (Brussels I) 9474/11 ADD 7 JUSTCIV 106 CODEC 7008 June 2011.

81 European Parliament Resolution of 7 September 2010 on the implementation and review of Council Regulation (EC) No 44/2001 on jurisdiction and the recognition and enforcement of judgments in civil and commercial matters P7_TA (2010)0304, paras 9 and 10 .

82 Ibid, paras 9 and 10 .

83 Ibid, point (M).

84 Draft Report of 28 June 2011 on the proposal for a regulation of the European Parliament and of the Council on jurisdiction and the recognition and enforcement of judgments in civil and commercial matters (recast) $(\mathrm{COM}(2010) 0748-\mathrm{C} 7-0433 / 2010$ - 2010/0383(COD)) (Rapporteur: Tadeusz Zwiefka), recital 11.

$85 \mathrm{Ibid}$; the proposed recital 11 provides that: 'This Regulation does not apply to arbitration. It does not apply to the form, existence, validity or effects of arbitration agreements, the powers of the arbitrators, the procedure before arbitral tribunals, and the validity, annulment, and recognition and enforcement of arbitral awards. The whole matter of arbitration should be excluded from the scope of this Regulation. Consequently, this Regulation does not apply to any dispute, litigation, or application which the parties have subjected to an arbitration agreement or settlement or which 
President of the Council suggested that the arbitration exclusion be retained whilst inserting a new recital that would clarify that a judgment on the merits where an arbitration agreement has been nullified would come within the scope of the Brussels I Regulation, and the position was accepted in the COREPER (that is, the Committee of Permanent Representatives), as well as by the majority of the Member States. ${ }^{86}$

Following the protracted discussions, the President of the Council invited the Council by its note of 1 June 2012 to adopt as a compromise package the draft general approach set out in the working document. ${ }^{87}$ The footnote to Art 84(2) of the draft general approach contained a new recital which explained the scope of the arbitration exclusion in the operative part of the Brussels I Regulation. ${ }^{88}$ The draft general approach was approved by the Council. ${ }^{89}$ The European Parliament withdrew its earlier position and took the view that the best solution was to retain the status quo that is to leave arbitration wholly outside the scope of application of the Brussels I Regulation whilst explaining the application of the arbitration exclusion in the recital. ${ }^{90}$ Therefore a compro-

relates to arbitration by virtue of an international treaty. Likewise, this Regulation does not apply to any dispute or decision concerning the existence or validity of an arbitration agreement or settlement, or to any provisional or preventive measure adopted in the context of a dispute, litigation or application which the parties have subjected to an arbitration agreement or settlement or which relates to arbitration by virtue of an international treaty.'

${ }^{86}$ General approach from the Presidency to Coreper/Council 10027/12 ADD 1 JUSTCIV 185 CODEC 133016 May 2012; Illmer, 'Commentary on Art 1' (n 72) 60.

87 Proposal for a Regulation of the European Parliament and of the Council on jurisdiction and the recognition and enforcement of judgments in civil and commercial matters (Recast) - First reading 10609/12 JUSTCIV 209 CODEC 14951 June 2012; Proposal for a Regulation of the European Parliament and of the Council on jurisdiction and the recognition and enforcement of judgments in civil and commercial matters (Recast) - First reading 10609/12 JUSTCIV 209 CODEC 1495 ADD 11 June 2012.

${ }_{88}$ Ibid, Art 84(2); the text of the recital to Art 84(2) is reproduced in recital 12 of the Brussels I Recast.

${ }^{89}$ See generally, European Parliament/Legislative Observatory [http://www .europarl.europa.eu/oeil/popups/ficheprocedure.do?lang $=$ en $\&$ reference $=2010$ / 0383(CO)] accessed 27 June 2015; Opinion of Advocate General Wathelet in Case C-536/13 Gazprom v Lithuania [2015] ECLI:EU:C:2015:316, paras 93-124.

90 Comment by Tadeusz Zwiefka (Rapporteur) on behalf of the Committee on Legal Affairs, on the Proposal for a Regulation of the European Parliament and of the Council on jurisdiction and the recognition and enforcement of judgments in civil and commercial matters (recast) 19 November 2012 [http://www.europarl.europa.eu/sides/ getDoc.do?pubRef=-//EP//TEXT+CRE+20121119+ITEM-017+DOC+XML+V0//EN \&language $=\mathrm{EN}]$ accessed 1 July 2015. 
mise position was reached by the European Parliament and the Council. ${ }^{91}$ The European Parliament adopted the Brussels I Recast and its adoption was based on the Committee on Legal Affairs' Report. ${ }^{92}$ The Council also adopted the Brussels I Recast and its recitals on 6 December 2012.

The legislative history of the Brussels I Recast demonstrates that the adoption of the new recital 12 of the Brussels I Recast that deals with the arbitration exclusion was the product of a political compromise between those that did not want any change in the scope of the arbitration exclusion and those who wanted the Brussels I Regime to expressly regulate arbitration in the form of an express provision in the body of the Brussels I Regime. The Brussels I Recast came into force on 10 January $2015^{93}$ and applies to 'legal proceedings instituted, to authentic instruments formally drawn up or registered and to court settlements approved or concluded on or after 10th January $2015^{\prime}, 4$ whilst the Brussels I Regulation continues to apply to judgments given in legal proceedings instituted, to authentic instruments formally drawn up or registered and to court settlements approved or concluded before 10th January 2015 , ${ }^{95}$ The innovative provisions in the new recital 12 of the Brussels I Recast seem to favour the process of arbitration as it provides better clarity on the scope of the arbitration exclusion in the Brussels I Recast than its predecessors, the Brussels I Regulation and the Brussels Convention. Recital 12 of the Brussels I Recast excludes arbitration from its scope, leaving the regulation of arbitration to the national laws of the Member States, as well as to the New York Convention.

Furthermore, it is imperative to point out at this stage that the most recent decision of the CJEU in the Gazprom case ${ }^{96}$ also provides useful guidance on the scope of the arbitration exclusion. In particular, the CJEU drew the

91 Opinion of Advocate General Wathelet in Case C-536/13 Gazprom v Lithuania (n 14) para 122; Peter Arnt Nielsen, 'The New Brussels I Regulation' (2013) CML Rev 503; Peter Arnt Nielsen, 'The Recast Brussels I Regulation' (2014) NordicJIL 61.

92 European Parliament legislative resolution of 20 November 2012 on the Proposal for a Regulation of the European Parliament and of the Council on jurisdiction and the recognition and enforcement of judgments in civil and commercial matters (recast) P7_TA (2012) 0412; European Parliament/Legislative Observatory 2010/0383(COD) - 50/11/2012 Text adopted by Parliament, 1st reading/single reading [http://www .europarl.europa.eu/oeil/popups/summary.do?id=1234824\&t=e\&l=en] accessed 27 June 2015; The Committee on Legal Affairs of 15 October 2012 on the Proposal for a Regulation of the European Parliament and of the Council on jurisdiction and the recognition and enforcement of judgments in civil and commercial matters (recast) (COM(2010)0748 - C7-0433/2010 - 2010/0383(COD)).

93 Brussels I Recast (n 5) Art 81.

94 Ibid, Art 66(1).

95 Ibid, Art 66(2).

96 Case C-536/13 Gazprom v Lithuania (n 14). 
boundary between matters falling within the material scope of the Brussels I Regulation and matters that fall outside its scope by virtue of the arbitration exclusion. In that regard, the CJEU held that the scheme of the Brussels I Regulation does not prohibit the Member States from recognising and enforcing or from refusing to recognise and enforce arbitral awards as the recognition and enforcement of arbitral awards fall outside the scope of the Brussels I Regulation. ${ }^{97}$ The CJEU also clarified that arbitrators are not bound by the principle of mutual trust which the Member States accord to each other's legal systems and judicial institutions. ${ }^{98}$ However, the CJEU did not specifically rule on how to interpret the new provisions in recital 12 of the Brussels I Recast. Against this background, there is currently no CJEU case law on the interpretation and application of the arbitration exclusion in the EU current legislative framework on jurisdiction. Therefore, this book provides useful guidance on interpreting the scope of the arbitration exclusion in the Brussels I Recast.

\subsection{BREXIT, THE NEW YORK CONVENTION AND THE BRUSSELS I REGIME}

Given that the UK has exited the EU as well as the fact that the New York Convention is cited as one of the main reasons for excluding arbitration from the material scope of the EU Brussels I Regime, ${ }^{99}$ it is necessary to briefly explore the scope of the New York Convention in order to ascertain the extent of its coverage. The basic point is that the impact of Brexit on international arbitration in the UK and the interface between arbitration and court litigation in the EU cannot be effectively addressed without examining the scope of the New York Convention that is applicable to the UK as well as to all the EU Member States.

The New York Convention facilitates the enforcement of arbitration agreements and the recognition and enforcement of foreign arbitral awards. ${ }^{100} \mathrm{It}$ is considered to be one of the most successful, and indeed highly influential, private international law instruments due to its widespread application. ${ }^{101} \mathrm{At}$ the time of writing, there are 159 Contracting States who are signatories to the New York Convention, including the UK and all the Member States of the

\footnotetext{
Ibid, paras 41-45.

Ibid, para 37.

Jenard Report (n 37) 13.

100 See Arts II, IV and V of the New York Convention (n 2); ICCA'S Guide to the Interpretation of the 1958 New York Convention (2011) 15.

101 Michael Mustill, 'Arbitration: History and Background' (1989) JIntlArb 43, 48.
} 
EU. ${ }^{102}$ The New York Convention replaced the 1927 Geneva Convention on the Execution of Foreign Arbitral Awards, ${ }^{103}$ which in turn replaced the 1923 Geneva Protocol on Arbitration Clauses. ${ }^{104}$ The New York Convention covers two important aspects of international commercial arbitration: (1) the enforcement of arbitration agreements and (2) the recognition and enforcement of foreign arbitral awards. ${ }^{105}$ The importance of this coverage is twofold. Firstly, the courts of Contracting States of the New York Convention have a treaty obligation to refer parties to arbitration where the parties have entered into an arbitration agreement, unless the agreement is 'null and void, inoperative or incapable of being performed'. ${ }^{106}$ Secondly, arbitral awards falling within the scope of the New York Convention will be recognised and enforced by the Contracting States subject, of course, to the grounds for refusal of recognition and enforcement contained in Art V of the New York Convention. ${ }^{107}$ Art I(1) of the New York Convention uses a territorial criterion to outline its scope of application:

This Convention shall apply to the recognition and enforcement of arbitral awards made in the territory of a State other than the State where the recognition and enforcement of such awards are sought, and arising out of differences between persons, whether physical or legal. It shall also apply to arbitral awards not considered as domestic awards in the State where their recognition and enforcement are sought. ${ }^{108}$

The New York Convention is broadly construed to cover all commercial matters save in cases where a Contracting State has made a commercial reservation in accordance with Art I(3) of the New York Convention. Similarly, Art 1 of the Brussels I Recast sets out the material scope of its application, which is that the Brussels I Regime 'shall apply in civil and commercial matters whatever the nature of the court or tribunal'. ${ }^{109}$ The term 'civil and commercial

102 A list of all the Contracting States of the New York Convention is available at [http://www.newyorkconvention.org/contracting-states/list-of-contracting-states] accessed 18 January 2016.

103 The 1927 Geneva Convention came into force in July 1929.

104 The 1923 Geneva Protocol entered into force on 28 July 1924 and it laid the foundation for the global recognition of international commercial arbitration.

105 Opinion of Advocate General Darmon in Case C-190/89 Marc Rich \& Co v Societa Italiana Impianti SpA [1991] ECR 1-03855, para 9; Albert van den Berg, The New York Arbitration Convention of 1958: Towards a Uniform Judicial Interpretation (Kluwer Law and Taxation Publishers 1981) 1-7.

106 New York Convention (n 2) Art II(3).

107 Ibid, Arts III, IV and V.

108 Ibid, Art I(1).

109 Brussels I Recast (n 5) Art 1. 
matters' is not expressly defined in the Brussels I Regime, but the concept is autonomously interpreted without reference to any of the internal laws of the EU Member State concerned. ${ }^{10}$ The CJEU has pointed out in a number of cases that the term:

Civil and commercial matters must be regarded as an independent concept to be interpreted by referring, first, to the objectives and scheme of the Brussels Convention and, second, to the general principles which stem from the corpus of the national legal systems. ${ }^{111}$

This ensures that the rights and obligations which are derived from the Brussels I Regime for the EU Member States and the persons to whom it applies are equal and uniformly interpreted. ${ }^{12}$ Accordingly, the scope of the Brussels I Regime is determined 'essentially by the elements which characterise the nature of the legal relationships between the parties to the dispute' and the subject matter of the action. ${ }^{113}$ The Brussels I Regime is widely construed to cover all the main civil and commercial matters apart from certain matters that are excluded from its material scope by virtue of Art 1(2)(a)-(f). This means that commercial matters which are covered under the Brussels I Regime may also be covered by the New York Convention. It follows that although both instruments, the New York Convention and the Brussels I Regime, pursue their respective policy objectives, they determine the jurisdiction of the courts of the EU Member States in civil and commercial matters. Whereas the New York Convention determines the jurisdiction of arbitral tribunals and the courts of the EU Member States seised of arbitration-related matters, the Brussels I Regime determines the jurisdiction of the courts of EU Member States in matters falling within its material scope. This means that although the UK is no longer an EU Member State, its obligation as a Contracting State of the New York Convention to recognise and enforce arbitration agreements/

110 Case C-292/05 Eirini Lechouritou and Others v Dimosio tis Omospondiakis Dimokratias tis Germanias [2007] ECR I-01519, para 29.

111 Case C-343/04 Land Oberösterreich v ČEZ as [2006] ECR 04557, para 22; Case C-292/05 Eirini Lechouritou (n 110) para 29; Case 29/76 LTU Lufttransportunternehmen GmbH \& Co KG v Eurocontrol [1976] ECR 01541, para 3; Case 133/78 Henri Gourdain v Franz Nadler [1978] ECR 00733, para 3; Case 814/79 Netherlands State v Reinhold Rüffer [1980] ECR 03807, para 7.

112 Case C-292/05 Eirini Lechouritou (n 110) para 29.

113 Case C-190/89 Marc Rich (n 4) para 26; Case C-292/05 Eirini Lechouritou (n 110) para 30; Case C-536/13 Gazprom v Lithuania (n 14) para 29; Case C-645/11 Land Berlin v Ellen Mirjam Sapir and Others [2013] ECLI:EU:C:2013:228, para 32; Report on the accession of the Hellenic Republic to the Community Convention on jurisdiction and the enforcement of judgments in civil and commercial matters [1986] OJ C298/1 (hereinafter referred to as Evrigenis and Kerameus Report) para 26-28. 
arbitral awards continues regardless of Brexit, likewise the remaining EU Member States. Accordingly, Brexit does not affect the operation of the New York Convention, nor does it affect the obligations of the Contracting States. It follows that arbitral awards given under the New York Convention will continue to be recognised by the Contracting States of the New York Convention post-Brexit but subject, of course, to the grounds for refusal contained in Art V of the New York Convention.

The basic fact is that arbitration is excluded from the scope of the Brussels I Recast, and Art 73(2) is clear that the Brussels I Recast shall not affect the application of the New York Convention. Accordingly, the New York Convention governs the field of arbitration, which is excluded from the scope of the Brussels I Regime. ${ }^{114}$ Therefore, the issue is not really whether there is overlap between the New York Convention and the Brussels I Regime, as the scope of both instruments differ and the operation of the New York Convention is not supposed to be affected by the Brussels I Regime; ${ }^{115}$ rather, the crux of the matter is that there is no proper method of regulating the arbitration/litigation conflict when it emerges, as in the West Tankers case. Consequently, the narrative on the arbitration exclusion in the Brussels I Regime is to some extent based on a wrong premise that the New York Convention adequately provided for arbitration, thereby excluding the regulation of arbitration from the scope of the Brussels I Regime. Essentially, what the provision on the arbitration exclusion actually means in practice is that the exclusion of arbitration from the scope of the Brussels I Regime does not allow for the resolution of conflict between the two types of dispute resolution (arbitration and litigation).

At the pre-award stage of the arbitration process, an EU Member States' court seised of a matter in which the parties have made an arbitration agreement is required to enforce the agreement by referring the parties to arbitration. ${ }^{116}$ That court may have to determine the issue of classification - for example, whether the arbitration agreement is formally and substantively valid - prior to referring the parties to arbitration. The formal validity concerns the form in which the agreement is expressed, such as the writing requirement of the arbitration agreement, whereas the substantive validity concerns all other issues, such as the consent of the parties, legality of the arbitration agreement and capacity of the parties to conclude the arbitration agreement. ${ }^{117}$ The reason for determining the scope, existence and validity of the arbitration agreement is that a valid arbitration agreement will divest the court of jurisdiction whilst

114 Case C-536/13 Gazprom v Lithuania (n 14) para 43.

115 Brussels I Recast (n 5) Art 73(2).

116 New York Convention (n 2) Art II(3).

117 Zheng Sophia Tang, Jurisdiction and Arbitration Agreements in International Commercial Law (Routledge 2014) 21. 
conferring jurisdiction on the arbitral tribunal to resolve the dispute on the merits. In other words, where the arbitration agreement is valid, it takes the commercial matter outside the scope of the Brussels I Regime by virtue of Art 1(2)(d). This means that the mere allegation by a commercial party that an arbitration agreement is valid does not automatically take the matter outside the scope of the Brussels I Regime, but the validity of the arbitration agreement will trigger the application of the arbitration exclusion in Art 1(2)(d) of the Brussels I Recast. Accordingly, where an EU Member State's court seised of a commercial matter in which the parties have made an arbitration agreement is satisfied that the agreement is valid, the Brussels I Regime will not apply and that court is obliged under the New York Convention to refer the parties to arbitration. The relevant provision of the New York Convention is found in Art II(3), which provides that:

The court of a Contracting State, when seised of an action in a matter in respect of which the parties have made an agreement within the meaning of this article, shall, at the request of one of the parties, refer the parties to arbitration, unless it finds that the said agreement is null and void, inoperative or incapable of being performed. ${ }^{118}$

To a certain degree, this mechanism in Art II(3) of the New York Convention tries to coordinate the jurisdiction of arbitral tribunals and national courts by obliging the court seised of a matter in which the parties have made an arbitration agreement to refer the parties to arbitration where the agreement is valid. However, the provision of Art II(3) of the New York Convention does not completely regulate the jurisdiction of courts and arbitral tribunals as the Convention is silent on a number of issues. ${ }^{119}$ For example, the New York Convention is silent on the extent to which the courts of the Contracting States are allowed to review the scope of arbitration agreements before referring the parties to arbitration. It does not prevent the courts of the Contracting States, prior to referring the parties to arbitration, from carrying out either a prima facie or full review of the arbitration agreement. ${ }^{120}$ Therefore, whether a court should undertake a full or prima facie review of the arbitration agreement prior to referring the parties to arbitration is dependent on the nature of competence-competence operational in the jurisdiction concerned. Whereas some national courts may carry out a full review of the existence and validity

118 New York Convention (n 2) Art II(3).

119 Brozolo (n 75) 425; Bermann (n 8) 401; Jacques Werner, 'Should the New York Convention Be Revised to Provide for Court Intervention in Arbitral Proceedings?' (1989) JIntlArb 113, 114.

${ }_{120}$ ICCA's Guide to the Interpretation of the 1958 New York Convention: A Handbook for Judges (International Council for Commercial Arbitration 2011) 40. 
of arbitration agreements, other courts may conduct a prima facie review of the arbitration agreement in order to determine the validity and existence of that arbitration agreement. In addition, the New York Convention does not provide a comprehensive regime for the exercise of court jurisdiction in arbitration matters; nor does it completely address the arbitration/litigation interface. The New York Convention is equally silent on the forum (arbitral tribunals and national courts) that will have the priority to determine the validity and existence of arbitration agreements. Accordingly, both the national courts and arbitral tribunals have the competence to determine the validity and existence of arbitration agreements. Surely, this allows the possibility of parallel court/ arbitration proceedings and conflicts between arbitration awards and judgments of national courts, especially where the arbitration agreement is considered valid by the arbitral tribunal and invalid by the national court.

As the New York Convention does not completely regulate the jurisdiction of courts and arbitral tribunals and as the EU Member States cannot unilaterally amend the New York Convention to address the problem of the arbitration/litigation interface at the international level, the pertinent question, therefore, is whether the EU Member States can agree amongst themselves to adopt rules on arbitration in order to address the problem at the regional EU level? In other words, can the EU Member States adopt modern rules that provide more favourable provisions on arbitration under the Brussels I Regime than the New York Convention? And contrary to the perceived view by some of the EU Member States, will the partial inclusion of arbitration within the scope of the Brussels I Regime affect the operation of the New York Convention? These questions are indeed relevant as the need to safeguard the operation of the New York Convention was one of the political reasons why Art 29(4) of the European Commission's proposal was rejected. The answer to these questions may be found in examining the provisions of Art VII of the New York Convention that regulates the Convention's relationship with other multilateral or bilateral treaties and with the national laws of the Contracting States. Art VII of the New York Convention provides that:

The provisions of the present Convention shall not affect the validity of multilateral or bilateral agreements concerning the recognition and enforcement of arbitral awards entered into by the Contracting States nor deprive any interested party of any right he may have to avail himself of an arbitral award in the manner and to the extent allowed by the law or the treaties of the country where such award is sought to be relied upon. ${ }^{121}$

121 New York Convention (n 2) Art VII. 
The provisions of Art VII(1) of the New York Convention are twofold: whereas the first provision, which may be called the compatibility provision, clarifies that the New York Convention shall not affect the validity of other treaties concerning the recognition and enforcement of arbitral awards, the second part, the more favourable right provision, allows an interested party to rely on a more favourable provision of a national or international law. ${ }^{122}$ This means that the crucial test of determining if other treaties and/or national law may be relied on where the New York Convention is applicable is whether the provisions of the treaty and/or national law include a more favourable provision than the Convention. There are several bilateral or multilateral treaties which may cover the same arbitration agreements and awards as that covered by the New York Convention. ${ }^{123}$

Art VII shows that the New York Convention is liberal concerning its relationship with other treaties. ${ }^{124}$ However, opinions differ as to the application of Art VII of the New York Convention. On the one hand, it has been argued that the liberal nature of the New York Convention does not ipso facto mean that a party can combine the provisions of the New York Convention with other treaties. In other words, a party may either rely on the provisions of the New York Convention as a whole or rely on the provisions of other treaties which include more favourable provisions. ${ }^{125}$ On the other hand, it has been argued that an interested party may rely on the more favourable provisions of other treaties even where recognition and enforcement is sought under the New York Convention. ${ }^{126}$ The latter view seems to be more in line with the main objective of the New York Convention, which facilitates the recognition and enforcement of foreign arbitral awards on the basis of either its own provisions

122 Ibid, Art VII(2).

123 For example, Convention on the Settlement of Investment Disputes between States and Nationals of Other States, Washington 1965; European Convention on International Commercial Arbitration 1961; Convention on the Enforcement of Judgments among States of the Arab League, Cairo 1952; The Inter-American Convention on International Arbitration, Panama 1975; The Convention on the Settlement by Arbitration of Civil Law Disputes Resulting from Economic, Scientific and Technical Co-operation, Moscow 1972. 90.

124 Albert Jan van den Berg, The New York Arbitration Convention of 1958 (n 18)

125 However, Albert Jan van den Berg accepted that two treaties may be combined where the treaties so imply, for example the 1961 European Convention on International Commercial Arbitration may be combined with the New York Convention as the European Convention complements the New York Convention in certain cases. Albert Jan van den Berg, The New York Arbitration Convention of 1958 (n 18) 85-86.

126 Julian DM Lew, Loukas A Mistelis and Stefan M Kröll, Comparative International Commercial Arbitration (Kluwer Law International 2003) 697-698. 
or those of another instrument. ${ }^{127}$ Moreover, the drafters of the New York Convention never intended to replace other treaties in the field of arbitration, but the objective was to adopt a new legal regime for the recognition of arbitration agreements and the recognition and enforcement of foreign arbitral awards. $^{128}$

It is, of course, important to mention that the more favourable right provision in Art VII of the New York Convention refers only to the recognition and enforcement of arbitral awards. However, Art VII has been construed to apply not only to the recognition and enforcement of arbitral awards, but also to the interpretation of arbitration agreements. ${ }^{129}$ This is because the recent developments in commercial transactions have shown that the writing requirement of Art II(2) of the New York Convention does not seem to accord with the modern ways of concluding commercial contracts as technological developments in recent times have made the writing requirement not entirely realistic. ${ }^{130}$ Art II(2) of the New York Convention was previously interpreted to impose an international minimum requirement which prevailed over national law on the form of arbitration agreements covered by the Convention. ${ }^{131}$ Consequently, it was believed that the New York Convention sets a uniform standard that prevents the courts of the Contracting States from applying more favourable formal requirements of arbitration agreements under their national law. ${ }^{132}$ This no longer seems to follow as Art II(2) of the New York Convention has been construed in light of Art VII(1) that allows an interested party to rely on a more favourable national law. ${ }^{133}$ In particular, UNCITRAL (that is, the United Nations Commission on International Trade Law), in its thirty-ninth

127 New York Convention Guide, para 16, Art VII [http://newyorkconvention1958 .org/index.php?lvl=cmspage\&pageid=11\&provision=143] accessed 8 February 2016.

128 Ibid, Art VII.

129 Loukas Mistelis and Domenico di Peitro, 'New York Convention, Article VII (Most Favourable Laws)' in Loukas Mistelis (ed) (2nd edn, Kluwer Law International 2015) 27-29.

130 Hong-Lin $\mathrm{Yu}$, 'Written Arbitration Agreements - What Written Arbitration Agreements?' (2013) Civil Justice Quarterly 68, 68.

131 Albert Jan van den Berg, 'Consolidated Commentary Cases Reported in Volumes XXII (1997) - XXVII (2002)' (2003) XXVII Yearbook Commercial Arbitration 562, 581-597; Switzerland No.14, Tracomin SA v Sudan Oil Seeds Co Ltd, Tribunal Federal (1987) XII Yearbook Commercial Arbitration 511; Pieter Sanders foreword in the ICCA's Guide to the Interpretation of the 1958 New York Convention: A Handbook for Judges (2011) VI and 43-44.

132 ICCA's Guide to the Interpretation of the 1958 New York Convention: A Handbook for Judges (2011) 44.

133 Recommendation regarding the interpretation of Article II, paragraph 2, and Article VII, paragraph 1, of the Convention on the Recognition and Enforcement of Foreign Arbitral Awards, done in New York, 10 June 1958, adopted by the United 
session, recommended that Art II(2) of the New York Convention should be broadly applied 'recognising that the circumstances described therein are not exhaustive'. ${ }^{134}$ UNCITRAL further recommended that Art VII(1) of the New York Convention should not only apply to the recognition and enforcement of arbitral awards, but should be applied to allow 'any interested party to avail itself of rights it may have, under the law or treaties of the country where an arbitration agreement is sought to be relied upon, to seek recognition of the validity of such an arbitration agreement'. ${ }^{135}$ The reason is that the New York Convention aims to promote the development of international arbitration and Art VII of the New York Convention allows Contracting States to adopt modern arbitration laws which a party may rely on provided the provisions of the treaties and/or national law are more favourable than the provisions of the New York Convention. Accordingly, Art 7 of the UNCITRAL Model Law on the definition and form of arbitration agreements was amended in 2006 to bring its provisions in conformity with the modern ways of concluding arbitration agreements. ${ }^{136}$

In principle, Art VII shows that the New York Convention does not prevent the development of arbitration; nor does it prevent the adoption of modern provisions on arbitration. Commercial parties may then rely on those provisions insofar as they include more favourable provisions than the New York Convention. Therefore, one can correctly argue that Art VII of the New York Convention does not prevent the EU Member States from adopting more favourable provisions on arbitration under the Brussels I Regime, such as applying a uniform law in the interpretation of arbitration agreements or

Nations Commission on International Trade Law on 7 July 2006 at its thirty-ninth session.

134 Ibid, para 1.

135 Ibid, para 2.

136 UNCITRAL Model Law on International Commercial Arbitration 1985 as amended in 2006, Art 7; Explanatory note by the UNCITRAL Secretariat on the Model Law on International Commercial Arbitration 1985 with amendments as adopted in 2006,27 . It is important to point out that arbitration agreements may be concluded orally in some jurisdictions. Thus, oral arbitration agreements are now recognised as having the same force as written arbitration agreements and can also be enforced accordingly. Following the amendments of the UNCITRAL Model Law on the form of arbitration agreements, some countries such as France and Scotland have recognised both oral and written arbitration agreements as a formal requirement of arbitration agreements. Whereas Art 1507 of the French Arbitration Law 2011 states that arbitration agreements shall not be subject to any requirement as to form, Art 4 of Arbitration (Scotland) Act 2010 provides that 'an arbitration agreement is an agreement to submit a present or future dispute to arbitration (including any agreement which provides for arbitration in accordance with arbitration provisions contained in a separate document).' 
enhancing the powers of the seat court whilst restricting the powers of the other courts of the Member States. These provisions may then be relied on by interested parties as they are more favourable than the New York Convention. The reason is as follows. Firstly, the New York Convention does not provide a uniform law that may be applied to interpret arbitration agreements at the pre-award stage. This means that different laws may be applied by the EU Member States' courts to examine the validity and existence of arbitration agreements where the parties omit to choose the law that will govern the arbitration agreement. Surely, this uncertainty in the application of different laws absent parties' choice may lead to conflicting decisions on the interpretation of arbitration agreements.

Secondly, the New York Convention does not give priority to either the seat court or the arbitral tribunal to determine the validity and existence of arbitration agreements; nor does it contain a comprehensive provision that regulates the jurisdiction of courts and arbitral tribunals. So, unlike the Brussels I Regime that contains a lis pendens mechanism which prevents parallel proceedings between two EU courts, it does not prevent parallel proceedings either between two courts or between an arbitral tribunal and a national court seised of the same matter. Although the New York Convention allows a Contracting States' court seised of a matter in respect of which the parties have made an arbitration agreement to determine the validity and existence of the arbitration agreement prior to referring the parties to arbitration, it does not specifically prevent the court from staying its jurisdiction in favour of the seat court or the arbitral tribunal where it is challenged on the basis of the arbitration agreement. The proposed Art 29(4) of the European Commission Recast Proposal to enhance the powers of the seat court is intended to safeguard the effectiveness of arbitration agreements within the EU by preventing the occurrence of parallel court/arbitration proceedings and the risk of inconsistent decisions which could affect the free movement of decisions within the EU. Indeed, it is in line with the goals of the New York Convention, which ensures the recognition and enforcement of arbitration agreements and awards. Incorporating specific provisions on arbitration within the material scope of the Brussels I Regime in order to address the arbitration/litigation interface at the EU level would not affect the operation of the New York Convention provided that the provisions contain more favourable outcomes.

Interestingly, it is important to point out that a number of non-EU States already regulate some aspects of arbitration at the regional level even though they are signatories to the New York Convention, and as such bound to apply its rules. ${ }^{137}$ Therefore, it is submitted that the operation of the New York

137 The Inter-American Convention on International Arbitration, Panama 1975. 
Convention would not be undermined within the EU if the EU Member States were to agree amongst themselves to regulate arbitration at the regional EU level by adopting modern arbitration laws, and commercial parties could rely on them insofar as the rules contain more favourable provisions than the New York Convention. Finally, what must be borne in mind is that Brexit does not affect the operation of the New York Convention, and the UK as well as the EU Member States will continue to discharge their treaty obligations under the New York Convention post-Brexit. In addition, the New York Convention does not prevent the development and adoption of modern arbitration laws, and in particular it ensures by virtue of Art VII(1) that 'whenever the New York Convention proves to be less favourable than the provisions of another treaty or law of the country where recognition or enforcement is sought' by an interested party seeking to avail himself of an arbitral award, the more favourable rules contained in those treaties or law shall prevail over the rules of the New York Convention. ${ }^{138}$

\subsection{PROVISIONAL CONCLUSIONS}

It follows from the foregoing discussion that a comprehensive and detailed analysis must be carried out to determine the impact of Brexit on international arbitration in the UK as well as the effect of the Brussels I Recast on the EU arbitration/litigation interface. This is necessary as the interface between international commercial arbitration and the Brussels I Regime remains an area that needs to be explored further. Arbitration has come to occupy a central role in the resolution of international commercial disputes, and the jurisdiction of courts of the UK as well as the remaining EU Member States cannot fully be established without having regard to the extent of their powers in respect of arbitration-related matters. Thus, it is important to examine the relationship between international commercial arbitration and the Brussels I Regime and to determine whether the direction of the legislative development by the EU legislators support the smooth functioning of international commercial arbitration within the EU, as well as whether it is in line with the international obligations of the Member States under the New York Convention.

This book will contribute to knowledge in this area by exploring the issues and by furthering the debate on the EU arbitration/litigation interface as well as the potential impact of Brexit on international arbitration. Arbitration practitioners will benefit from understanding the implications of arbitrating within the EU, particularly the interactions between arbitral tribunals and the

138 New York Convention Guide, Art VII, para 5 [http://newyorkconvention1958 .org/index.php?lvl=cmspage\&pageid=11\&provision=143] accessed 8 February 2016. 
courts of the UK and the remaining EU Member States. It is believed that the findings will be relevant to the diverse, mobile and global international dispute resolution environment and other commercial arbitration. Legal strategies that mitigate the risk of inconsistent legal treatment of international adjudicatory conflicts will be to the advantage of arbitration in the UK and EU. Finally, the outcomes of this book offer guidance to policymakers, academics, arbitration practitioners, businesses, students and anyone wishing to understand the interaction of court litigation and international commercial arbitration in Europe, as well as to non-European domiciled businesses and commercial actors wishing to arbitrate within Europe and to academics and students that are interested in comparative research in international commercial arbitration. 